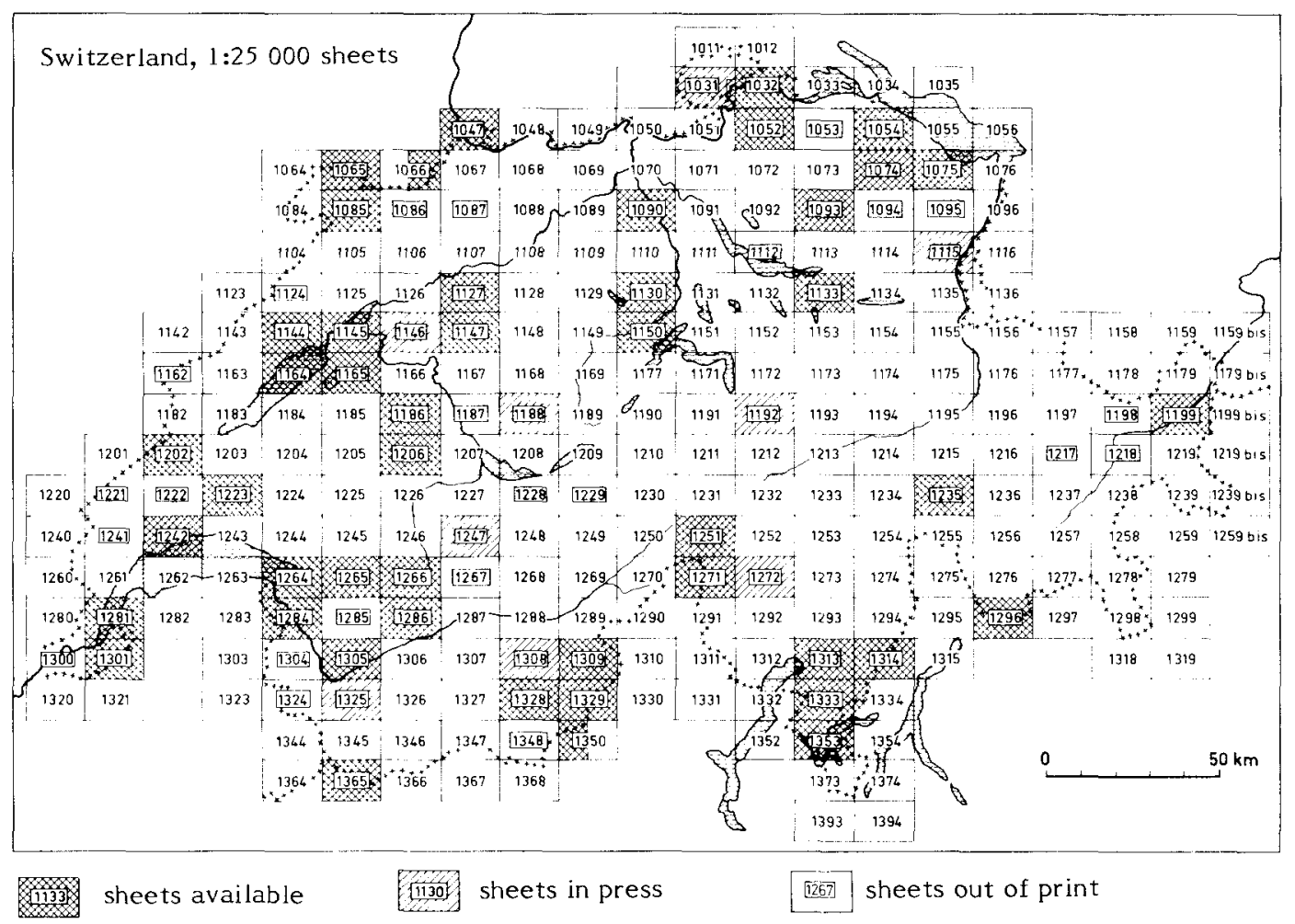

\section{SWITZERLAND (second edition)}

$1: 50000$

Carte Géologique de la Suisse

(A. Spicher 1972)

Carte Tectonique de la Suisse

(A. Spicher 1972)

$1: 200000$

Carte Géologique Générale de la Suisse

(in 8 sheets)
1. Neuchâtel (1944) avec notice explicative
2. Basel-Bern (1942) out of print
3. Zürich-Glarus (1950) out of print
4. St. Gallen-Chur (1959)
5. Genève-Lausanne (1948) out of print
6. Sion (1942) out of print
7. Ticino (1955) out of print
8. Engadine (1964)

A limited number of explanatory notes of sheets 2, 3, 5 and 6 are still available. Instead of an explanatory note there are available for sheets 4,7 and 8: a list of basic geological maps, a tectonic map and geological sections.
Price per sheet

Pire in pocket edition

Price of Expl. Note

Carte Géotechnique de la Suisse

1. Neuchâtel-Bern-Basel (1964)

2. Luzern-Zürich-St. Gallen-Chur (1963)

3. Geneve-Lausanne-Sion (1965)

4. Bellinzona-St. Moritz (1967)

Price per sheet

Sfr. 29.00

Sfr. 18.65

Sfr. 31.15 (in 4 sheets with explanatory notes)
Atlas Géologique de la Suisse (see sketch map)
$1: 25000$
Sfr. 29.50

Sfr. 29.50

Sheet Price in Sfr. Sheet

1032 Diessenhofen 24.75

1047 Basel

28.50

1052 Andelfingen 28.50

1054 Weinfelden

24.75

1065 Bonfol 28.50

1066 Rodersdorf $\quad 18.80$

1074 Bischofszell 28.50

1075 Rorschach 28.50

$1085 \mathrm{St}$. Ursanne 24.75

1090 Wohlen 28.50

$1093 \mathrm{Hörnli}$

1127 Solothurn

1130 Hochdorf

1133 Linthebene

$1144 \mathrm{Val}$ de Ruz

1145 Bieler See

1223 Echallens

1235 Andeer

1242 Morges

1251 Val Bedretto

1264 Montreux

1265 Les Mosses

1266 Lenk

1271 Basodino

Sfr. $\quad 3.00$

In press:

1031 Neunkirch

1115 Säntis

1146 Lyss

1188 Eggiwil

1192 Schächental

1281 Coppet

1284 Monthey

1286 St. Léonard

1296 Sciora

1301 Genève

1309 Simplon

1313 Bellinzona $\quad 28.50$

1147 Burgdorf $\quad 24.75$

1150 Luzern $\quad 24.75$

1164 Neuchâtel 28.50

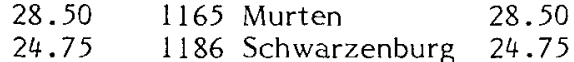

$28.50 \quad 1199$ Scuol-Schuls 28.50

$\begin{array}{lll}28.50 & 1202 \text { Orbe } & 24.75\end{array}$

$28.50 \quad 1206$ Guggisberg 24.75

$24.75 \quad 1314$ Passo di lorio 24.75

$28.50 \quad 1328$ Randa $\quad 28.50$

$28.50 \quad 1329$ Saas $\quad 24.75$

$28.50 \quad 1333$ Tesserete $\quad 24.75$

28.50 1350 Monte Moro 15.45

$28.50 \quad 1353$ Lugano $\quad 28.50$

24.751365 Grd. St. 24.75

24.75

Bernard

1247 Adelboden

1272 P. Campo Tencia

1308 St. Niklaus

1325 Sembrancher
Order address (up-to-date catalogues available):

Kümmerly \& Frey A.G.

Editions Géographiques

P.O. Box 3001, CH-3012 Bern, Switzerland 
MAPS AV AILABLE (Continued)

For general information:

- Guide géologique de la Suisse. Publié par la Société Géologique Suisse. Deuxième édition complè tement renouvelée comprenant des instructions générales (fasc. 1) et la description des excursions $1-44$ (fasc. 2-9), avec 1 planche en couleurs, 274 figures et 3 tableaux dans le texte. Edition Wepf \& Co. Bâle (Suisse), 1967.

- Aarmassiv und Gotthardmassiv. Von T.P. Labhart. Band

\section{BOLIVIA}

$1: 5000000$

Mapa Tectónico de Bolivia (1973) with explanatory note

$1: 2000000$ (Servicio Geológico)

Bosquejo Geológico de la

República de Bolivia

(Servicio Geológico)

1:1 212000

Mapa Geológico de Bolivia (1946)

in: F. Ahlfeld: Geológia de Bolivia (see below)

1:1000 000 (see sketch map)

Hojas Geoloǵicas

\section{Sketch Map: Bolivia}

63, Sammlung geologischer Führer, 173 Seiten, 22 Abb., 1 Tab. im Text, 1 Ubersichtskarte, 1 zweifarbige geologische Karte. Gebr. Borntraeger, Berlin/Stuttgart, 1977. Preis DM 36.00 .

- Eiszeitalter. Band I: Die jüngste Erdgeschichte der Schweiz und ihrer Nachbargebiete. Klima, Flora, Fauna, Mensch. Alt- und Mittelpleistozän. Vogesen, Schwarzwald, Schwäbische Alb, Adelegg. Von R. Hantke. Ott Verlag A.G., Thoune (Suisse), 1978.
Price US\$ 1.00

Price US\$10.00

For genera
F. Ahlfeld

Price per sheet

for 5747 with Bulletin

US\$ 6.00

$6140 "$ " US\$ 9.00

6435 " " US\$ 9.00

- Geología de Bolivia

Revista del Museo de La Plata (n.s.)

Sección Geologiá , Tomo 3, 1946

Order address:

Facultad de Ciencias Naturales y Museo Biblioteca, Paseo del Bosque

1900 La Plata, Argentina

Order address (for maps, except Ahlfeld's map):

Servicio Geológico de Bolivia

Calle Federico Zuazo No. 1673 Esq. Reyes Ortiź

Casilla 2729, La Paz, Bolivia.

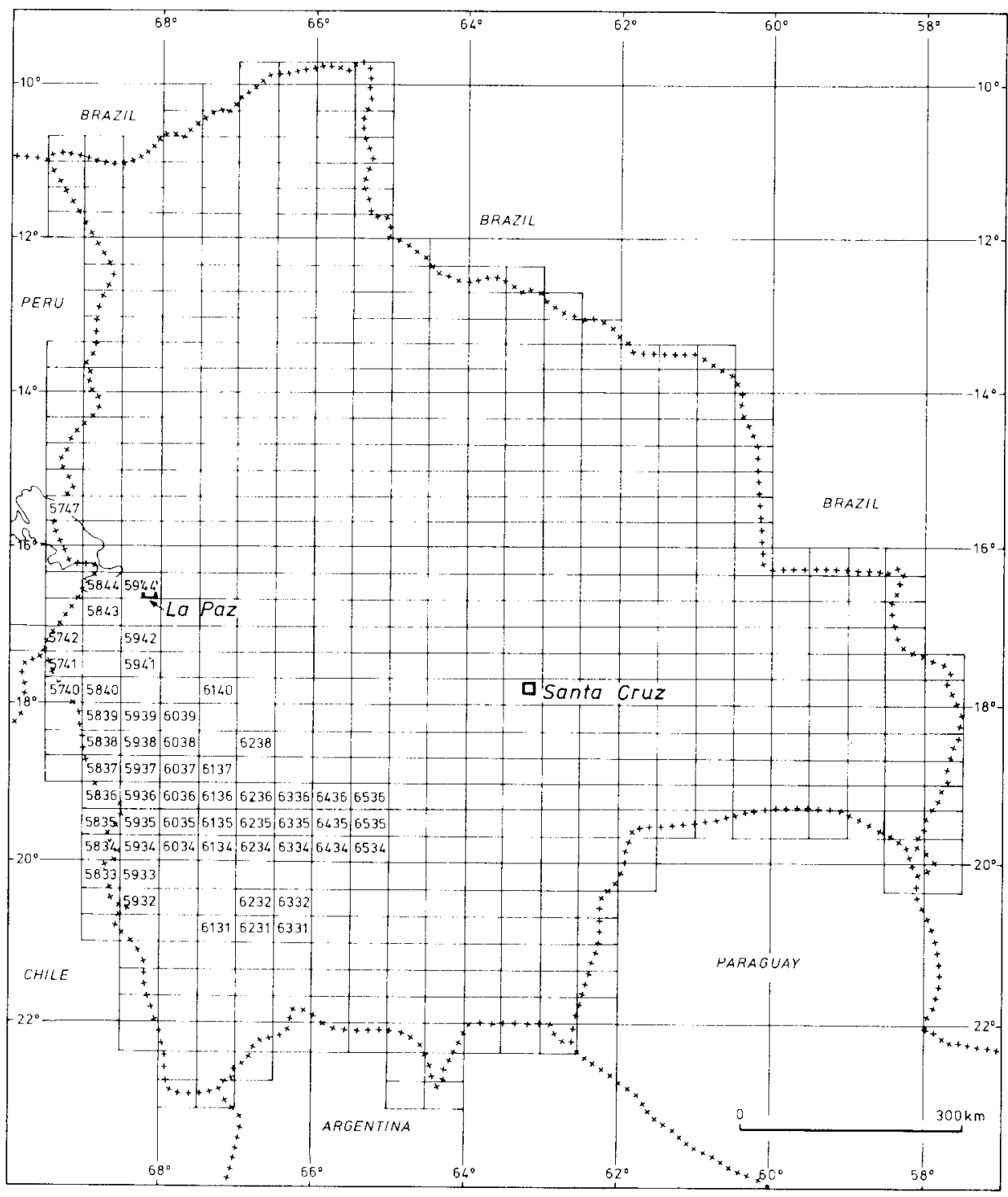




\section{THE EARTH'S TECTONOSPHERE ITS PAST DEVELOPMENT AND PRESENT BEHAVIOR}

\section{J. H. TATSCH}

We are pleased to announce that the first (1972) edition of The Earth's Tectonosphere has been completely revised. The new edition updates the results of our continuing research to determine the most probable geometrical, mechanical, thermal, and chemical aspects of the origin, evolution, and present behavior of the Earth's upper 1000 kilometers. Included are about 80 of John C. Holden's inimitable drawings.

More specifically, this book is a multiple-hypothesis analysis of the development of the Earth's internal structure during the past 4.6 billion years, of how this deep structure has controlled the Earth's internal behavior since the Earth began, and of why the surficial geophenomena and features are manifestations of that internal behavior.

Chapter headings: 1, The origin of the solar system; 2, The Earth-Moon system; 3, The Tectonospheric Earth Model; 4, The Earth as a planet; 5, The crust of the Earth; 6, The tectonosphere; 7, The orogenic-cratonic structure of the continents; 8, The Earth's deep seismicity; 9, Global patterns of geothermal activity; 10, Intrusive and extrusive activity; 11, Morphology of the Earth; 12, Mountain building; 13, The Earth's gravity field; 14, Geomagnetism and polarity reversals; 15, Continents and oceans; 16, Sea-floor spreading; 17, Continental drift and polar wandering; 18, Plate tectonics and related omniductive processes; 19, Asteroids, meteorites, and tektites; 20, The integrated Earth and its future.

The Tectonospheric Earth Model concept, developed in the first edition and repeated in this edition, differs essentially from other global-tectonics concepts in two salient respects: (1) it embodies the geometrical, mechanical, thermal, and chemical aspects of a driving mechanism that has existed during the entire 4.6 billion years that the Earth is believed to have been in existence; and (2) it encompasses the Earth's spatio-temporal framework to a depth of $1000 \mathrm{~km}$ during these 4.6 billion years.

The second edition attempts to show, as did the first, how these two differences permit a more meaningful interpretation of the origin, evolution, and present characteristics of the Earth's behavior than is possible through other globaltectonics concepts. This pertains not only to the Earth's lithospheric plates but to all plates, blocks, and other forms of material that have evolved within the upper 1000 $\mathrm{km}$ of the Earth during the past 4.6 billion years.

The Tectonospheric Earth Model has been used as the basis for 10 correlative follow-on books: Mineral Deposits (1973), The Moon (1974), Petroleum Deposits (1974), Copper Deposits (1975), Gold Deposits (1975), Uranium Deposits (1976), Geothermal Deposits (1976), Earthquakes (1977), Coal Deposits (in press), and Iron Deposits (in preparation).

Available directly from the publisher or through book dealers in all parts of the world. Hard cover, $6 \times 9$ inches, 468 pages. Table of contents, line drawings, maps, bibliography, index. \$30. LC:74-78917. ISBN:0-912890-03-7. 1977.

\section{Tatsch Associates}

120 THUNDER ROAD

SUDBURY, MASSACHUSETTS 01776

U. S. A. 